pág. 80), pois sacrifica o conteúdo à forma $e$ a qualidade à quantidade. Mais instabilidade política na América Latina, com suas formas específicas, não significa que instabilidade politica não exista em um grau maior nos Estados Unidos, por exemplo. Sòmente aqui ela se manifesta com formas diferentes. A França teria sido subdesenvolvida durante a IV República? A menos que politica se refira ao nivel institucional e se fale em desenvolvimento político, tão divulgado entre os cientistas sociais, sobretudo norte-americanos. Mas essa é uma visão funcionalista e, por conseguinte, limitada da política que, aliás, o autor não tem em outras partes de seus ensaios. Mas, não deixa de mostrar as diferentes concepções de instabilidade política e seu papel no processo de subdesenvolvimentodesenvolvimento, êste relacionado dinâmicamente (e esquemàticamente) com o processo de urbanização. Finalmente, 0 autor tenta responder à pergunta "o que entender por desenvolvimento do tipo macroestrutural capitalista?" (p. 114 e segs.). Sua crítica a Gunder Frank parece-me bastante justa ( $p$. 118).

4. "Brasil: etapa contemporânea". Tratase de um texto preparado para o público alemão, e é válido dizer que o público brasileiro também aproveitará de sua leitura. Aqui, o autor conclui que "o destino do capitalismo no Brasil está ligado, desde 1964, ao êxito ou fracasso da realização do desenvolvimento associado ou interdependente a que o Estado serve instrumentalmente como agente poiitico e econômico" (p. 158).

Estamos, portanto, diante de ensaios bastante úteis, principalmente ao público especializado. Pois se deve dizer que não se trata de leitura fácil, principalmente para os que não estão habituados com um determinado tipo de terminologia. Ainda mais que a complexidade do assunto leva o autor a constantes esquematizações, cujo perigo êle não ignora. A outro nível pode-se lamentar certas fórmulas artificiais, compreensíveis no âmbito das ciências sociais brasileiras no momento atual, pois elas tornam o simples mais complexo e, às vêzes, podem conduzir-nos a erros (a competição subentende, em geral, obediência a certas regras; assim competição politica é limitativo do conceito clássico marxista). Compreenda-se o autor e diga-se que os objetivos apresentados na nota prévia estão justificados.

BRÁS JOSÉ ARAƯJo

\title{
Curso de Rotinas Trabalhistas
}

Por José Serson. 2. ed. São Paulo, Editôra LTR, 1971.

Como comentar uma obra que procura modificar, ou, mais do que isso, inovar muito do que já foi tratado em matéria de direito trabalhista? Como comentar uma obra que transformou a difícil e complicada linguagem juridica numa linguagem fácil, simples e de rápida assimilação?

Lógico que não seria tarefa das mais ingratas ler e comentar a obra. Ocorre que para ter podido elaborar uma resenha que desse ao leitor visão necessária à compreensão do texto de Curso de rotinas trabalhistas (CRT), foi necessária uma conversa bastante informal com o seu autor.

José Serson, professor e juiz do trabalho, deu detalhes que podem ser considerados da maior importância. Vamos a um trecho dessa entrevista :

Luís César - Logo que corri os olhos no índice do cRT, julguei que fôsse encontrar um 
livro ligado estreitamente à esfera jurídica. E evidente que, ao ler o primeiro capítulo, senti a ausência dos artigos, parágrafos, diversos caputs e outros têrmos jurídicos da maneira como são tratados comumente. Tentei, então, identificar o porquê do livro, seu objetivo e...

José Serson - Não é difícil explicar. O objetivo do livro é mostrar como o direito do trabalho se efetiva em procedimentos administrativos na emprêsa; sob êsse aspecto, não se encontra matéria nem nos textos legais, nem em seus comentaristas, que se importam em dar a interpretação do texto, mas não a forma de sua aplicabilidade ao cotidiano da vida empresarial. Este livro encara o direito trabalhista, e também, em certas etapas, aspectos do direito previdenciário e tributário, corporificados em maneiras de agir, considerando a forma como êsses ramos do direito repercutem na ação do administrador.

LC - Tenho notado a existência de uma razoável dificuldade na interpretação de textos legais tanto por aquêles que trabalham mais diretamente na administração de pessoal, como também por estudantes das escolas de administração. Está-me parecendo, conforme seu primeiro comentário, que CRT visa a minimizar ou eliminar esta dificuldade. Certo?

JS - Certo. Os livros de direito são redigidos, em maior ou menor intensidade, em linguagem técnica própria da ciência jurídica, com expressões peculiares, com têrmos que só os iniciados compreendem. Escrevi CRT do jeito que estamos conversando, da maneira como se fala e se escreve nas emprêsas.

LC - Você dividiu CRT em seis rotinas, muito claras e muito definidas. Esta sistematização eu não encontrei nem nos textos legais, nem nos textos comentados.
JS - A divisão, em seis rotinas, de todos os aspectos de aplicação do direito do trabalho às emprêsas, foi um verdadeiro achado. Através dessa divisão foi possível sistematizar as atividades empresariais voltadas ao cumprimento da legislação trabalhista, como nunca antes se houvera feito. Dentro dêsse sistema, cada atividade tem o seu lugar, momento e formas próprias...

LC - Chega um momento em que as atividades se entrosam, ou seja, se complementam, certo?

$$
\text { JS - Isso. }
$$

LC - Esste livro é retrato fiel dos cursos que você ministra na FIESP/cIEsP. Da convivência com mais de 2.000 alunos, o que você considera ter sido a maior contribuição ao CRT?

JS - Nestes cursos, cada aluno tem sua experiência pessoal. O que coletei enriqueceu sobremaneira o texto. Há dois pontos em que o interêsse dos alunos é mais freqüente: quando estudamos os cálculos decorrentes de desligamento, acoplando o rGTs com os esquemas tradicionais.

$$
\text { LC - Explique melhor. }
$$

JS - Conseguiu-se um equacionamento que oferece, em matéria tão complexa como é o FGTS, 27 hipóteses diferentes de desligamento. Vai ser difícil encontrar a 28. ${ }^{\mathrm{a}}$.

$$
\text { LC - Falta o outro ponto de interêsse. }
$$

JS - Este surge quando estudamos as repercussões tributárias do pagamento feito a empregados, autônomos e avulsos; trata-se de matéria legislativa muito vasta e dispersa onde existem decisöes administrativas numerosíssimas e nem sempre muito coerentes, 0 que dificulta o procedimento do administrador; ainda nesse campo, logramos um equa- 
cionamento muito feliz, enquadrando tôdas as situações de maneira a tornar fácil e segura a decisão do administrador.

$\mathrm{E}$ assim foi. A edição de Curso de rotinas trabalhistas tem o mérito de, além de dar um embasamento necessário à análise trabalhista-administrativa, é acessível a todos, desde o mais simples dos auxiliares de pessoal até o mais notável dos jurisconsultos.
O leitor encontrará nas páginas desta publicação da LTr, todos os formulários oficiais, bem como sua forma correta de preenchimento. Não há dúvida de que êste ingrediente a mais vem de encontro ao enfoque da conversa mantida com José Serson, qual seja a de tornar claro o que a lei pode tornar escuro àqueles que não dominem a ciência jurídica.

LUÚS CÉSAR GONÇALVES DE ARAÚJO

\section{Tapirapé: Tribo Tupi no Brasil Central}

Por Herbert Baldus. São Paulo, Companhia Editôra Nacional, 1970. 511 p., il. (Brasiliana Editôra Nacional, 1970. 511 p., il. (Brasiliana Gigante, 17).

Herbert Baldus, etnólogo de formação européia, radicado no Brasil desde o comêço da década de 30 , é autor de uma série de livros sôbre os indígenas brasileiros. Seus trabalhos anteriores foram publicados na Revista do Museu Paulista, na Coleção Brasiliana, e alguns dêles saíram publicados, também, nos Estados Unidos e Europa. Dentre êles, podemos citar: Ensaios de etnologia brasileira, Manual bibliográfico de estudos brasileiros $\mathrm{e}$ Dicionário de etnologia e sociologia.

Tapirapé: tribo tupi no Brasil central é uma obra que descreve minuciosamente a cultura tapirapé, comparada, nos seus distintivos, com as culturas das tribos vizinhas e outras tribos tupis. O material básico para sua elaboração foi colhido pelo próprio autor nas duas visitas que fêz aos tapirapés, a primeira em 1935 e a segunda em 1947.

Afirma Baldus que êles são o povo mais alegre que já conheceu. Assustam-se com facilidade, mas com a mesma facilidade voltam a sorrir. Embora não dêem muita importância aos instrumentos musicais, gostam do canto. Amam muito seus filhos, sendo bastante afetuosos para com êles. A infância, entretanto, é curta. As crianças já ajudam os pais no trabalho, não havendo muito tem- po para jogos e brincadeiras infantis. Há, entretanto, um fenômeno curioso: a instituiçäo da criança preferida. Esta seria uma espécie de mascote da tribo. Diferencia-se das outras crianças por não ter que ajudar no trabalho, estar sempre bem arrumada e viver na companhia dos homens mais importantes da tribo. E seu dever ser amável com todos.

Quanto à religião, revelam originalidade em relação às outras tribos. Acreditam que as fôrças sobrenaturais estão localizadas horizontalmente nas extremidades da terra habitada pelos homens e não por cima ou por baixo dêles. Acreditam, também, num mundo subterrâneo, tendo os antepassados saído do centro da terra.

O universo tapirapé é dualista: esta concepção surge da idéia da existência de dois casais dando origem à tribo, como na sua divisão em metades cerimoniais, ou seja, a existência de fenômenos duais nas festas e ritos. Como exemplo, temos os tata-upaua, ou grupos de comer: em festas cspeciais, a tribo se divide em dois grandes grupos, para o consumo de alimentos. Cada uma dessas. metades possui chefes distintos, que teòricamente se igualam em poder. 